\title{
HYDRAULIC STUDIES OF DRIP IRRIGATION SYSTEM UNDER USING LOW QUALITY WATER CONDITIONS
}

\author{
Rania A. A. Alkersh(1), Kh. F. El-Bagoury(2), \\ Ebtisam I. Eldardiry(1) and A. M. El-Gindy(2)
}

ABSTRACT

Laboratory experiments were carried out at Water Relations and Field Irrigation Dept., National Research Centre (NRC), El-Dokki, Cairo, Egypt to evaluate hydraulic parameters for five emitter types and select the best for applying in field experiments at NRC farm. Then a field experiment was conducted in Research and Production Station, NRC, ElNobaria, El-Beheara Governorate, Egypt, in 2015/2016 to study the effect of selected emitter's types under different water salinity, on the plant growth characteristics and yield of turnip crop.

Lab experiments were conducted to evaluate hydraulic parameters for five emitter types [On-line emitter NEIN-ETF, Built in (GR), pressure compensating emitters (NEIN-PC), Pressure compensating and Self-flushing emitter (EDEN-PC) and On-line Commercial Katif emitter (KATIF-R-P-201] under water salinity $(345,2000,4000,6000$, and $8000 \mathrm{ppm})$ and different operating pressure heads $(0.8,1.0,1.2,1.4,1.6,1.8$, and 2 bar). While in field experiment which was carried out to study the effect of some selected emitters [On-line Commercial Katif (CK), Built-in GR (GR), and On-line NEIN ETF, (ETF)] under different water salinity, (2000 and 4000 ppm in addition to the canal water, 345 ppm) on the plant growth characters and yield of turnip (Brassica rapa $L$ ).

Results of a lab experiment, in the case of using NPC1, NPC2 and NPC3 at using water salinity 345, 2000 and 4000 ppm were the highest in application efficiency, uniformity coefficient. It could be concluded that emitter types of NPC1, NPC2, and NPC3 under using water salinity 345, 2000, and 4000 ppm were the best and could be recommended to apply in the field research work.

(1) Water Relations and Field Irrigation Dept., National Research Centre, ElBehoos St., Dokki, Cairo, Egypt.

(2) Agricultural Engineering Department, Faculty of Engineering, Ain Shams University, Cairo, Egypt. 
According to field experiment, data revealed that the highest values of the estimated plant characters were attending at 345 ppm water salinity under all examined emitters. Emitter NPC1 gained the highest yield value (22.28 ton/fed) and NPC3 got the lowest one (19.23 ton/fed), while NPC2 emitter has a superior effect on yield and recorded the highest values which ranged from 27.5; 19.1 ton/fed at 354; $4000 \mathrm{ppm}$ and 12.99, $8.22 \mathrm{~kg} / \mathrm{m}^{3}$, respectively, while Emitter NPC1 gained the highest yield value $(22.28$ ton/fed) and NPC3 got the lowest one (19.23 ton/fed) with difference $16 \%$, while NPC2 recorded the highest water use efficiency, WUE $\left(10.77 \mathrm{~kg} / \mathrm{m}^{3}\right)$. WUE for examined emitters, NPC2 had a positive effect and recorded increase about $14.5 \%(N P C 1)$ and $17.4 \%$ (NPC3). The rate of reduction in yield and WUE relative to salinity were 20 and $35 \%$ for irrigation water salinity 2000 and 4000 ppm relative to control one (345 ppm).

Keywords: Hydraulic, drip irrigation, Emitter types, water salinity, turnip, water use efficiency.

\section{INTRODUCTION}

$\Gamma$ The efficiency of the irrigation system is the most important factors in the design and management of micro-irrigation system, so the increase in crop production is the vital goal and the big investment on farms and smallholdings alike. Since the emitter is the most critical component of the drip irrigation system, which is designed to discharge water consistently to plant root zone. The uniformity in flow rate from drippers is affected due to pressure variation, manufacturing variation, the temperature variation of the flowing water and dripper clogging. Drip irrigation has many benefits, but one of the most serious problems in the system is dripper clogging. It is attributed to a number of factors and is classified into physical, chemical and biological properties (Shinde et al., 2012). Salinity could be one of the main causes of emitter clogging in a drip irrigation system, which builds up either from irrigation water and/or fertigation process. Emitter clogging depends on upon its water discharge capacity, where the emitters with large nominal discharge, self-flushing, and pressure compensating features recorded less flow rate reduction than less nominal discharge emitters (Hezarjaribi $\boldsymbol{e t}$ al., 2008; Aali et al., 2009). Choosing emitters with higher discharge 
rates might be important due to the highly clogging percentage, which observed in the smaller discharge rate emitter than higher discharge one (Bozkurt and Ozekici, 2006). Water quality is important when the water contains high amounts of soluble cations, especially with $\mathrm{SO}_{4}{ }{ }$ and/or $\mathrm{HCO}_{3}{ }^{=}$owing to the high risk of emitter clogging and consequently system performance (Sanij et al., 2001; Ribeiro et al., 2004).

Emitter clogging may be due their extreme small passages of water and low flow rate (Ozekici, 1998). Kulkarni (2005) added that more clogging emitters were found at the end of the drip laterals than at the beginning probably due pressure head loss. Hebbar et al. (2004) found that normal fertilizers generally tend to clog the emitters causing an uneven distribution of fertilizers. Phocaides (2000) carried a study on the effect of different fertigation practices on clogging of inline emitters using Samandag region well water in Turkey. Their data showed that different fertilizer treatments have a significant effect on emitter clogging. Fertilizers containing both $\mathrm{Ca}^{2+}$ and $\mathrm{SO}_{4}{ }_{4}$ caused higher clogging compared with the others. Mansour et al. (2013) said that as water flow in irrigation system slows down and/ or the chemical back- ground of the water changes, chemical precipitates and/or microbial flocks and slimes begin to form and grow, thus emitters clogging occur.

Uniform application (UA) of water in agriculture has a major impact on crop production and net farm income, where water is saved when irrigation uniformity is improved. Ideally, all emitters in micro irrigation should deliver equal quantity at irrigation process (Phocaides, 2000). The uniformity in flow rate from emitters is affected by pressure variation, manufacturing variation, the temperature of the flowing water and emitter clogging (Reinders et al., 2005; Mansour et al., 2015). A number of studies on the drip irrigation system with the use of saline or sodic water for irrigation were done. The water, having a high $\mathrm{pH}$ or $\mathrm{EC}$ was responsible for decrease emitter efficiency. A non-uniform distribution not only can deprive portions of the crop of needed water, but, furthermore, can over irrigate portions of a field, leading to waterlogging, plant injury, salinization, and transport of chemicals into the ground water (Amor et al., 2014). Distribution uniformity (DU) is 
defined as a measure of the uniformity with which irrigation water is distributed to different areas in a field.

Koegelenberg et al. (1999) studied the uniformity of manufacture of emitters; small manufacturing differences between emitters may cause significant variations in discharge. The coefficient of manufacturing variation (CV) is used as a measure of the anticipated variation in discharge for a sample of new emitters (Uys, 2000; Van Niekerk, 2006). They added that $\mathrm{CV}$ is a very useful parameter with rather consistent physical significance because the discharge rate for emitters at a given pressure is essentially normally distributed. The physical significance of $\mathrm{CV}$ is derived from the classic bell-shaped normal distribution curve in which:

- Essentially all the observed discharge rates fall within $(1 \pm 3 \mathrm{CV})$ of the average discharge rate;

- Approximately $95 \%$ of the discharge rates fall within $(1 \pm 2 \mathrm{CV})$ of the average discharge rate;

- Approximately $68 \%$ of the discharge rates fall within $(1 \pm 1 \mathrm{CV})$ of the average discharge rate; and they state that the average of the lowest quarter of the discharge rates is approximately equal to $(1-\mathbf{1 . 2 7} \mathbf{C V})$ to the average discharge rate.

Wan et al. (2007) found in three years trails using saline irrigation water (1.1 to $4.9 \mathrm{dS} \mathrm{m}^{-1}$ ) under drip irrigation system and exported that water salinity had little effect on tomato yields, but had some effect on the seasonal accumulative water use, water use efficiency, and irrigation water use efficiency. However, when sufficient irrigation water is applied to eliminate accumulated salts in soil surface and/or root zone (Hill and Koenig, 1999). The aim of this research is to investigate the hydraulic evaluation for five emitter's types and the best three types, applied in the field experiments at NRC farm. They study the influence of different water salinity on the performance of selected emitters, Study the influence of various operation pressures on the performance of selected emitters, Evaluate the effect of water salinity and emitter type on the crop yield, select the emitter which achieves better results and determine the amount of irrigation water, which can be saved using the accurate emitter. 


\section{MATERIAL AND METHODS}

Laboratory experiments were carried out at Water Relations and Field Irrigation Department, National Research Centre (NRC), El-Dokki, Cairo, Egypt to evaluate hydraulic parameters for five emitter types and select the best for applying in field experiments at NRC farm. Then a field experiment was conducted in Research and Production Station, NRC, ElNobaria, El-Beheara Governorate, Egypt, in 2015/2016 to study the effect of selected emitters types under different water salinity, on the plant growth characteristics and yield of turnip (Brassica rapa $\mathrm{L}$ ).

\section{Soil and irrigation water}

Lab experiment was carried out at Water Relations and Field Irrigation Department, National Research Centre (NRC), El-Dokki, Cairo, Egypt to evaluate hydraulic parameters for five emitter's types and select the best for applying in field experiments at NRC farm.

A field experiment was carried out in the Experimental Farm of Agricultural Production and Research Station, National Research Centre (NRC), El Nubaria Province, Egypt, sandy soil (latitude 30.8667N, and longitude $30.1667 \mathrm{E}$, and mean altitude $21 \mathrm{~m}$ above sea level). The soil type of this site is sandy loam textured. Some soil chemical properties were measured in the laboratory of Soil Department. NRC as follows: Soil $\mathrm{pH}$ and EC were measured in 1:1 (soil: water suspension) and in soil paste extract, respectively. The total available water within the soil depth and the mean bulk density varies as shown in Table (1).

\section{Table (1): Soil properties of the experimental site.}

\begin{tabular}{|c|c|c|c|c|c|c|c|c|c|c|c|c|}
\hline \multirow{2}{*}{$\begin{array}{l}\text { Depth } \\
\text { (cm) }\end{array}$} & \multirow{2}{*}{$\begin{array}{c}\text { pH } \\
1: 2.5 \\
\end{array}$} & \multirow{2}{*}{$\begin{array}{l}E C, \\
d S / m\end{array}$} & \multicolumn{4}{|c|}{ Particle Size distribution, \% } & \multirow{2}{*}{$\begin{array}{l}\text { Texture } \\
\text { Class }\end{array}$} & FC & \multirow[t]{2}{*}{ PWP } & \multirow{2}{*}{$\frac{\mathrm{AW}}{\mathrm{b}}$} & \multirow{2}{*}{$\begin{array}{c}\text { BD } \\
\left(\mathrm{g} / \mathrm{cm}^{3}\right)\end{array}$} & \multirow{2}{*}{$\begin{array}{l}\text { TP } \\
(\%)\end{array}$} \\
\hline & & & C. Sand & F. Sand & Silt & Clay & & (\% on & & & & \\
\hline-15 & 8.3 & 0.35 & 13.7 & 75.1 & 7.4 & 3.8 & Sandy & 13.15 & 5.23 & 7.9 & 1.53 & 40.38 \\
\hline 15-30 & 8.2 & 0.36 & 13.5 & 75.6 & 7.3 & 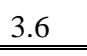 & Danting & 12.0 & 5.35 & 0.0 & 1.47 & 39.62 \\
\hline $30-45$ & 8.3 & 0.34 & 13.8 & 75.3 & 7.4 & 3.5 & Sandy & 13.02 & 5.7 & 7.0 & 1.48 & 38.11 \\
\hline $5-60$ & 8.4 & 0.73 & 13.9 & 74.6 & 7.6 & 3.9 & Sandy & 14.1 & 5.92 & 6.4 & 1.47 & 37.36 \\
\hline
\end{tabular}

FC: Field capacity; PWP: Permanent wilting point; AW: Available water; B.D: Bulk density, and TP: Total Porosity. 


\section{Chemical properties of irrigation water}

Chemical analysis of irrigation water was measured with using the standard methods and shown in Table (2). All the measured chemical parameters describe the status of the irrigation water and it can be used normally in irrigation.

Table (2): Some chemical properties of irrigation water.

\begin{tabular}{|c|c|c|c|c|c|c|c|c|c|c|c|c|}
\hline \multirow{2}{*}{$\begin{array}{c}\text { Water } \\
\text { sample }\end{array}$} & \multirow{2}{*}{$\mathrm{pH}$} & \multirow{2}{*}{$\begin{array}{c}\mathrm{EC} \\
\mathrm{dS} / \mathrm{m}\end{array}$} & \multirow{2}{*}{$\begin{array}{c}\mathrm{EC} \\
\mathrm{ppm}\end{array}$} & \multicolumn{8}{|c|}{ Soluble anions and cations (meq/l) } & \multirow{2}{*}{ SAR } \\
\hline & & & & $\mathbf{C a}^{++}$ & $\mathrm{Mg}^{++}$ & $\mathrm{Na}^{+}$ & $\overline{\mathbf{K}^{+}}$ & $\mathrm{CO}_{3}{ }^{=}$ & $\mathrm{HCO}_{3}^{-}$ & $\mathrm{SO}_{4}{ }^{=}$ & $\mathrm{Cl}^{--}$ & \\
\hline $\begin{array}{c}\text { Canal } \\
345 \mathrm{ppm}\end{array}$ & 7.34 & 0.845 & 474.88 & 2.01 & 1.68 & 2.88 & 0.85 & 0.0 & 0.47 & 3.01 & 3.94 & 2.12 \\
\hline $\begin{array}{c}\text { Well } \\
4321 \mathrm{ppm}\end{array}$ & 7.53 & 6.501 & 4160.64 & 21.23 & 18.28 & 23.35 & 2.15 & 0.0 & 0.53 & 28.24 & 36.24 & 5.25 \\
\hline $\begin{array}{c}\text { Mix } \\
\text { 2000ppm }\end{array}$ & 7.46 & 3.126 & 2000.64 & 9.65 & 7.85 & 13.41 & 0.35 & 0.0 & 0.46 & 9.54 & 21.26 & 4.53 \\
\hline
\end{tabular}

EC: Electrical conductive; SAR: Sodium absorption ratio.

\section{Climatic data}

The average climatic data during the evaluation months of growing season were obtained from Central Laboratory for Agricultural Climate (CLAC). Detailed daily values of weather data during the growing season are presented in Table (3).

Table (3): Average climatic data at the experimental site during the months of evaluation.

\begin{tabular}{|l|c|c|c|c|c|c|}
\hline \multicolumn{1}{|c|}{ Month } & $\begin{array}{c}\boldsymbol{T}_{\max } \\
\left({ }^{\circ} \mathrm{C}\right)\end{array}$ & $\begin{array}{c}\boldsymbol{T}_{\min } \\
\left({ }^{\circ} \mathrm{C}\right)\end{array}$ & $\begin{array}{c}\boldsymbol{R} \boldsymbol{H}_{\text {mean }} \\
(\boldsymbol{\%})\end{array}$ & $\begin{array}{c}\mathbf{N} \\
(\text { hours })\end{array}$ & $\begin{array}{c}\boldsymbol{u}_{2} \\
\left(\mathbf{m ~ s}^{-\mathbf{1}}\right)\end{array}$ & $\begin{array}{c}\boldsymbol{P} \\
(\mathbf{m m})\end{array}$ \\
\hline November & 24.4 & 13.2 & 61.3 & 10.6 & 2.22 & 17 \\
\hline Desember & 19.9 & 9.1 & 45.2 & 10.2 & 1.75 & 22 \\
\hline January & 18.3 & 7.6 & 48.2 & 10.4 & 1.37 & 18 \\
\hline February & 19.3 & 8.3 & 52.3 & 11.1 & 1.48 & 15 \\
\hline
\end{tabular}

\section{Irrigation system}

\section{a- Lab experiment}

The lab study used a laboratory-scale apparatus fitted with two laterals of PVC drip tubing, each $15 \mathrm{~m}$ in length. Each lateral contains 50 emitters 
with a space of $30 \mathrm{~cm}$. Water was supplied to the laterals from a Polyethylene, 500L $\left(0.5 \mathrm{~m}^{3}\right)$ supply tank using a 373 -watt $(0.5 \mathrm{hp})$, highpressure pump. Additionally, a flow meter was installed to record the total volume of water supplied to the system. The pressure in the laterals was regulated by a two bar regulator installed after the pump. One-liter measuring cylinders with $10 \mathrm{ml}$ divisions were used to collect the water from the emitters as shown in Figure (1).

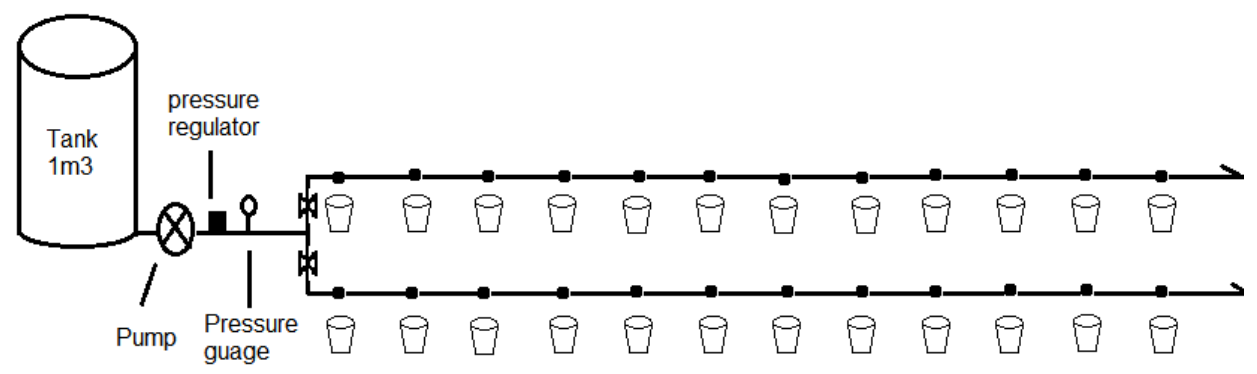

Fig. (1): Lab experiment layout.

\section{b- Field experiment}

For the field experiment, the total area of the experiment was $540 \mathrm{~m}^{2}$ and divided into nine main plots as shown in Figure (2). The system consists of the following components:

\section{a. Tank:}

Three Polyethylenes, $1 \mathrm{~m}^{3}$ tanks with a float inside was connected to the control head. The tanks are being filled with water through PVC pipe, 63 $\mathrm{mm}$ diameter and 6 bar operating pressure, derived from the main line of the farm.

\section{b. Pumping unit:}

\section{Pump}

Type: 4AMP180L4MY5.

RPM: 1450 - $50 \mathrm{HZ}$.

Pressure: 5.5 bar.

Flow rate: $70 \mathrm{~m}^{3} / \mathrm{h}$

Weight: $55 \mathrm{~kg}$.

\section{Motor}

Type: NT65-400/390, 4IB-W2, 4522356/15.

Power: $22 \mathrm{KW}$.

Voltage: 380-680 V- 3 PH.

Efficiency: 90\%. 


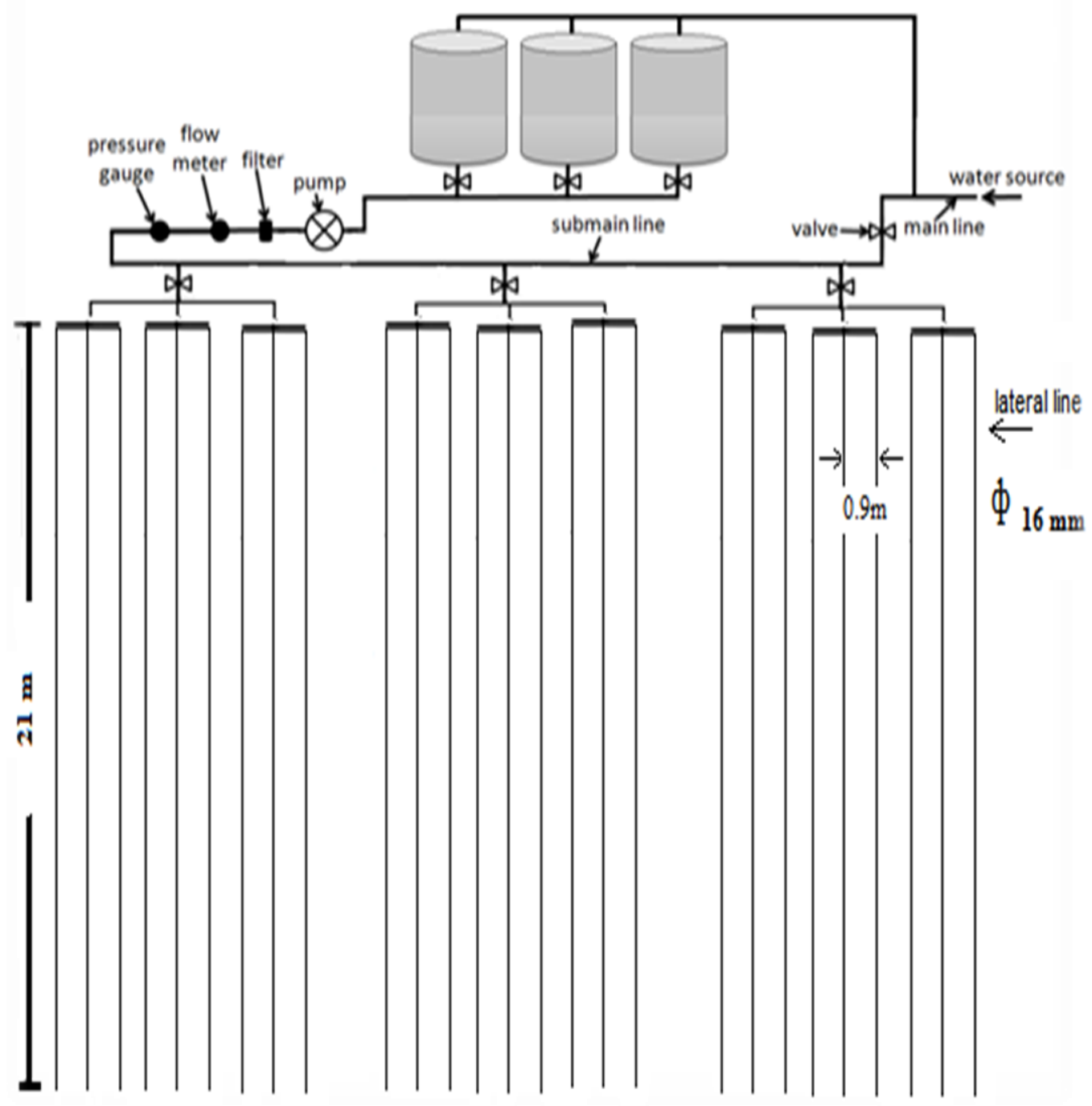

Fig. (2): The irrigation system components.

\section{c. Control head:}

It is located at the water inlet and consists of:-

- Injection unit: venture PE of 2", the range of suction capacity $34-279 \mathrm{l} / \mathrm{h}$.

- Filter: screen filter 1.5" (one unit), 155 mesh, Max. Flow $7.2 \mathrm{~m}^{3}$ $\backslash \mathrm{h}$ and maximum pressure 150 (PSI).

- Spring brass none return valve: 2inches. 
- pressure gauges: 0-10 bar

- Control valves: UPVC ball valve, 2-inch diameter and 6 bar operating pressure.

- Flow meter.

d. Mainline:

PVC pipe of $110 \mathrm{~mm}$ diameter connects the control unit for conveying the water to sub-main lines.

\section{e. Sub main lines:}

PVC $75 \mathrm{~mm}$ diameter line derived from the main line to feed the manifold lines.

\section{f. Lateral lines:}

PVC $63 \mathrm{~mm}$ diameter line connects to the sub-main lines to feed the group of risers.

g. Emitters: Five types of emitters were used in this experiment as shown in Table (4).

Table (4): Types of examined emitters' nominal characteristics.

\begin{tabular}{|c|c|c|}
\hline Emitter model & $\begin{array}{c}\text { Emitter } \\
\text { type }\end{array}$ & $\begin{array}{c}\text { NPC1 } \\
\text { Online }\end{array}$ \\
\hline NEIN-ETF & $\begin{array}{c}\text { NPC2 } \\
\text { Built-in }\end{array}$ \\
\hline GR & PC \\
NEIN ENEIN-PC & Online \\
\hline EDEN NEIN-PC & $\begin{array}{c}\text { PCS } \\
\text { Online }\end{array}$ \\
\hline KATIF & $\begin{array}{c}\text { NPC3 } \\
\text { Online }\end{array}$ \\
\hline Rivulis Plastro 201
\end{tabular}

PC: Pressure compensating, NPC: Non pressure compensating, PCS:

Pressure compensating and Self-flushing. 


\section{Turnip crop}

Turnip (BrassicarapaL) seeds were sown manually at 2/11/2015in two rows of each line at $10 \mathrm{~cm}$ between plant pits. The plants were harvested at 10/2/2015with total growth period was 100 days. The irrigation stopped 5 days before harvesting. Standard crop coefficients $(\mathrm{Kc})$ of the four growth stages (initial stage, crop development stage, mid-season stage, and late season stage) for turnip crop according to single-Kc are tabulated in Tables (5).

Turnip plants were taken from each line after 100 days from cultivation. Water Productivity: Water use efficiency (WUE) or Water Productivity (WP) for the crop under all treatments, $\left(\mathrm{kg} / \mathrm{m}^{3}\right)$, was computed by dividing of total root yield $(\mathrm{kg} / \mathrm{fed}) /$ total applied water $\left(\mathrm{m}^{3} / \mathrm{fed}\right)$ throughout the season.

\section{Table (5): Water requirement of the turnip crop.}

\begin{tabular}{c|c|c|c|c|c|c|c}
\hline \hline Month & \multicolumn{2}{|c|}{ Nov. } & \multicolumn{2}{c|}{ Dec. } & Jan. & Feb. \\
\hline \hline ETo (mm/day) & \multicolumn{2}{|c|}{2.88} & \multicolumn{2}{c|}{2.49} & 1.65 & 2.54 \\
\hline \hline \multirow{3}{*}{ Stage } & 20 & 8 & 22 & 9 & 26 & 5 & 10 \\
\cline { 2 - 7 } & $\begin{array}{c}\text { Initial stage } \\
\text { (20 days) }\end{array}$ & $\begin{array}{c}\text { Development stage } \\
\text { (30 days) }\end{array}$ & $\begin{array}{c}\text { Mid- season } \\
\text { (35 days) }\end{array}$ & $\begin{array}{c}\text { Late season } \\
\text { (15 days) }\end{array}$ \\
\hline \hline Kc & 0.5 & 0.8 & 1.10 & 0.6 \\
\hline \hline
\end{tabular}

All fertilizers were applied just before sowing in recommended doses from calcium super phosphate $\left(\begin{array}{llll}15 & \% & \mathrm{P}_{2} \mathrm{O} 5\end{array}\right)$ and potassium sulphate $\left(50 \% \mathrm{~K}_{2} \mathrm{O}\right)$ were applied during the preparation of the experimental soil. Ammonium sulphate was applied by $80 \mathrm{~kg} / \mathrm{fed}$ in three equal doses to the experimental plots as follows: 10, 20 and 30 days after germination. Herbicides and all other agro-technologies were applied according to standard practices.

\section{Calculation of water requirements}

Data of water requirements for turnip crop were calculated. According to the climatic data recorded at the nearest meteorological station, the average metrological parameters needed for the calculation were recorded using CROPWAT computer model and applying Penman-monteith equation and $\mathrm{K}_{\mathrm{c}}$ values presented in the program and also illustrated in Allen et al. (1998). Crop evapotranspiration ( $\left.\mathrm{Et}_{\mathrm{c}}\right)$ was calculated according to the following formula: 


$$
\mathbf{E T}_{\mathrm{c}}=\mathbf{K}_{\mathrm{c}} \cdot \mathbf{E} \mathbf{T}_{\mathrm{o}}
$$

Where

$\mathrm{ET}_{\mathrm{c}}=$ crop evapotranspiration in $\mathrm{mm} /$ day.

$\mathrm{ET}_{\mathrm{o}}=$ reference evapotranspiration in $\mathrm{mm} /$ day.

$\mathrm{K}_{\mathrm{c}}=$ crop coefficient.

\section{Emitters discharge}

A numerical method to measure the desirability of pressure, flow characteristics for a given emitter device is based on a flow rate vs. pressure curve $(\mathrm{Q}-\mathrm{H})$ fitted to an equation of the following form:

$$
\mathbf{Q}=\mathbf{k} \mathbf{H}^{\mathbf{x}} \text {. }
$$

Where: $\mathrm{Q}$ is the emitter flow rate, $\mathrm{m}^{3} / \mathrm{h} ; \mathrm{K}$ is the constant depending on emitter type; $\mathrm{H}$ is the operation, $\mathrm{m}$; and $\mathrm{x}$ is the exponent characteristics of emitters, unit less.

Exponent $x$ is an indication of the flow regime and emitter type. It is an indirect measure of the sensitivity of flow rate to the change in pressure. The value of $x$ typically ranges between $(0-1.0)$, where a lower value indicates a lower sensitivity and a higher value indicates a higher sensitivity. For PC emitters the value should be less than 0.1 and should approach 0. For NPC emitters, it should approach 0.5 (Cuenca, 1989).

As shown in Table (6), emitters with exponents less than 0.5 are entitled to be called pressure compensating, to different extents (CIT, 2002).

Table (6): Emitter exponent values for various flow regimes and

\begin{tabular}{|c|c|c|}
\hline Flow regime & Exponent x & Emitter type \\
\hline \multirow[t]{4}{*}{ Variable flow path } & $>0.1$ & \multirow{5}{*}{ Fully pressure compensating } \\
\hline & 0.1 & \\
\hline & 0.2 & \\
\hline & 0.3 & \\
\hline Vertical flow & 0.4 & \\
\hline Fully turbulent flow & 0.5 & \multirow{6}{*}{ Fon-pressure compensating } \\
\hline Mostly turbulent flow & 0.6 & \\
\hline & 0.7 & \\
\hline \multirow[t]{2}{*}{ Mostly laminar flow } & 0.8 & \\
\hline & 0.9 & \\
\hline Fully laminar flow & 1.0 & \\
\hline
\end{tabular}
emitters (Adapted from IA, 2002). 


\section{Emitters Clogging}

To estimate the emitter flow rate cans and a stopwatch was used. Nine emitters from each lateral had been chosen to be evaluated by calculating their clogging ratio at the beginning and at the end of the growing season for two seasons. Three emitters at the beginning, three at middle and threat the end of the lateral were tested for flow rate. Clogging ratio was calculated using the following equations (El-Berry et al., 2003):

$$
\begin{aligned}
& E=q u / q n * 100 \\
& C R=(1-E) 100
\end{aligned}
$$

Where:

$\mathrm{E}=$ the emitter discharge efficiency $(\%)$

$\mathrm{qu}=$ emitter discharge, at the end of the growing season $(\mathrm{L} / \mathrm{h})$

qn $=$ emitter discharge, at the beginning of the growing season $(\mathrm{L} / \mathrm{h})$

$\mathrm{CR}=$ the emitter clogging ratio $(\%)$

The pressure influence on emitter flow rate can be presented in two ways, either directly as the average of emitter flow rate or as a percentage of flow rate change that occurs at the actual operating pressure and pressure of 1 bar with the same water temperature, divided by the flow rate at a pressure of 1 bar according to (Keller and Karmeli, 1974) as follows:

$$
\text { q var }=\frac{\text { qmax }-\mathbf{q m i n}}{q \max } \times 100
$$

Where;

q var: the emitter flow variation,

$\mathbf{q}_{\text {max }}$ : the maximum emitter flow along the lateral line, $1 / \mathrm{h}$, and

$\mathbf{q}_{\text {min: }}$ the minimum emitter flow along the lateral line, $1 / \mathrm{h}$.

\section{Manufacturing coefficient of variation}

The coefficient of variation (CV) is defined as the ratio of standard deviations of the discharges (Madramootto, 1988). In the lateral design, emitter flow variation is used as a design criterion. The emitter flow variation comprises hydraulic variation and due to manufacturing variation among the emitters. The latter depends on the quality control in production. The unit to unit variation in the emitter flow was expressed by the following relationship: 


$$
\mathrm{CV}=\frac{\mathrm{s}}{\mathrm{qa}} \times 100
$$

Where:

CV: manufacturing coefficient of variation,

S: sample standard deviation and

q: average emission rate of the sample.

Table (7): Micro-irrigation system uniformity classification based on the coefficient of variation.

\begin{tabular}{l||l|l||l}
\hline \hline \multicolumn{3}{c}{ Point-source } & \multicolumn{2}{c}{ Line source } \\
\hline \hline$C_{\mathrm{v}}$ range & Classification & $\mathrm{C}_{\mathrm{v}}$ range & Classification \\
\hline \hline$<0.05$ & Excellent & $<0.10$ & Good \\
\hline \hline $0.05-0.07$ & Average & $0.10-0.20$ & Average \\
\hline \hline $0.07-0.11$ & Marginal & $>0.20$ & Marginal to Unacceptable \\
\hline \hline $0.11-0.15$ & Poor & & \\
\hline \hline 0.15 & Unacceptable & & \\
\hline \hline
\end{tabular}

*Adopted from ASABE Standards EP405.1, 2008R

The standard deviation of emitter flow rate, Sq, (ASABE, 2008R) can be written as:

$$
S=\sqrt{\frac{1}{n-1}} \sum_{i=1}^{n}(q i-q a)^{2}
$$

The coefficient of manufacture variable measures the variation in flow rate for a given emitter model at a normal operation pressure ranging from 0.2 to 2.0 bar and a water temperature of $\left(20-23^{\circ} \mathrm{C}\right)$. The emitter manufacture's coefficient of variation "CV" is one of the statical terms, which can be used to show the drip irrigation system uniformly.

\section{Emission uniformity}

Keller and Karmeli (1974) revealed that a statical uniformity could be used to indicate performance for emitters. Values were calculated according to the following equation:

$$
\mathbf{E U}=\frac{\mathbf{q n}}{\mathbf{q a}} \times 100
$$

Where EU: the emission uniformity, $\%, \mathrm{q}_{\mathrm{n}}=$ the average of lowest $1 / 4$ of the emitter flow rate, in $1 / \mathrm{h}$, and $\mathrm{q}_{\mathrm{a}}$ : the average of all emitter flow rates. 
Lab experiment was carried out to evaluate hydraulic parameters for five emitter types and select the best for applying in field experiments at NRC farm. Factors under study were water salinity (345, 2000, 4000, 6000; $8000 \mathrm{ppm}$ ) and emitter's types (NPC1, NPC2, NPC3, PC; PCS) under different operation pressure head $(0.8,1.0,1.2,1.4,1.6,1.8 ; 2$ bar).

Emitter discharge was measured (volumetrically and triplicated) over a range of seven pressures $(0.8,1.0,1.2,1.4,1.6,1.8$, and 2 bar) to determine the manufacturing variation of each type. A stopwatch was used to measure the flow times. The water volumes were collected in the graduated cylinders and manually read and recorded.

A field experiment was carried out to study the effect of selected emitters types (NPC1, NPC2, and NPC3) under different water salinity, (2000 and $4000 \mathrm{ppm}$ in addition to the canal water, $345 \mathrm{ppm}$ ) on the plant growth characters and yield of turnip (Brassica rapa $\mathrm{L}$ ).

Irrigation water of desired salinity level was prepared by mixing canal water $(345 \mathrm{ppm})$ with underground water (4321 ppm) and stored in a plastic tank of 1000 liters capacity. Irrigation process was carried out twice a week regarding the evapotranspiration (ETo) as well as leaching requirements that considered about $10 \%$ in all treatments.

The total area of the experiment was $540 \mathrm{~m}^{2}$ and divided into nine main plots as shown in Figure (3).

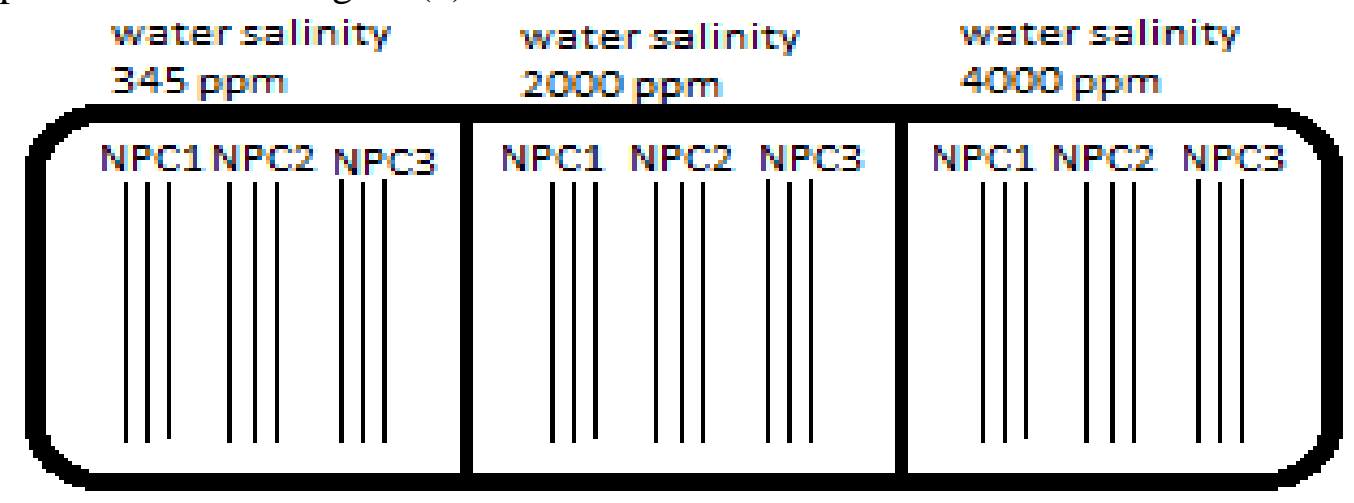

Fig. (3): layout of the experimental layout.

\section{Statistical analysis}

The data were subjected to the analysis of variance (ANOVA) appropriate to the randomized complete block design, factorial, applied after testing 
the homogeneity of error variances according to the procedure out- lined by Dospekhov (1984). The significant differences (LSD) between treatments were compared with the critical difference at the $5 \%$ probability level.

\section{RESULTS AND DISCUSSION}

\section{Calculation of water requirements}

Table (8) Water requirement of the turnip crop:

\begin{tabular}{|c|c|c|c|c|c|c|c|}
\hline Month & \multicolumn{2}{|c|}{ Nov. } & \multicolumn{2}{|c|}{ Dec. } & \multicolumn{2}{|c|}{ Jan. } & Feb. \\
\hline ETo $(\mathrm{mm} /$ day $)$ & \multicolumn{2}{|c|}{2.88} & \multicolumn{2}{|c|}{2.49} & \multicolumn{2}{|c|}{1.65} & 2.54 \\
\hline \multirow[b]{2}{*}{ Stage } & 20 & 8 & 22 & 9 & 26 & 5 & 10 \\
\hline & $\begin{array}{l}\text { Initial stage } \\
\text { (20 days) }\end{array}$ & \multicolumn{2}{|c|}{$\begin{array}{c}\text { Development stage } \\
\text { (30 days) }\end{array}$} & \multicolumn{2}{|c|}{$\begin{array}{l}\text { Mid- season } \\
\text { (35 days) }\end{array}$} & \multicolumn{2}{|c|}{$\begin{array}{l}\text { Late season } \\
\text { (15 days) }\end{array}$} \\
\hline Kc & 0.5 & \multicolumn{2}{|c|}{0.8} & \multicolumn{2}{|c|}{1.10} & \multicolumn{2}{|c|}{0.6} \\
\hline $\operatorname{ETc}(\mathbf{m m} /$ day $)$ & 1.44 & 2.30 & 1.99 & 2.74 & 1.82 & 0.99 & 1.52 \\
\hline $\left.\mathrm{ETcm}^{3} / \mathrm{day} / \mathrm{Fed}\right)$ & 6.1 & 9.7 & 8.4 & 11.5 & 7.6 & 4.2 & 6.4 \\
\hline $\operatorname{ETc}\left(\mathbf{m}^{3} /\right.$ tage/Fed $)$ & 122 & \multicolumn{2}{|c|}{543} & \multicolumn{2}{|c|}{668.5} & \multicolumn{2}{|l|}{159} \\
\hline $\operatorname{Etct}_{\text {otal }}\left(\mathrm{m}^{3} /\right.$ season/Fed $)$ & \multicolumn{7}{|c|}{1492.5} \\
\hline $\operatorname{IR}\left(\mathbf{m}^{3} /\right.$ season$\left./ \mathbf{F e d}\right)$ & \multicolumn{7}{|c|}{$=\frac{1492.5 \times(1+0.15)}{0.9}=1907.1$} \\
\hline
\end{tabular}

\section{Calibration of emitters:}

It is known that in a drip irrigation system is a positive relationship between the operating pressure and the emitter flow rate. This relationship may be affected by some changes in the physical properties of water; one of these changes is to increase the proportion of salt, which exists in lowquality water. Figure (4) illustrates the relation between the emitter flow rates with water salinity and operation pressure.

Regarding the effect of operation pressure on the flow rate of the different studied emitters NPC1,NPC2, PC, PCS, and NPC3), one can notice that increasing operation pressure associated with the increasing emitters flow rate. Also, the highest and lowest flow rate values as affected by increasing operating pressure for the examined emitters were attained at 1.6 and 0.8 bar, respectively as shown in Figure (4). 

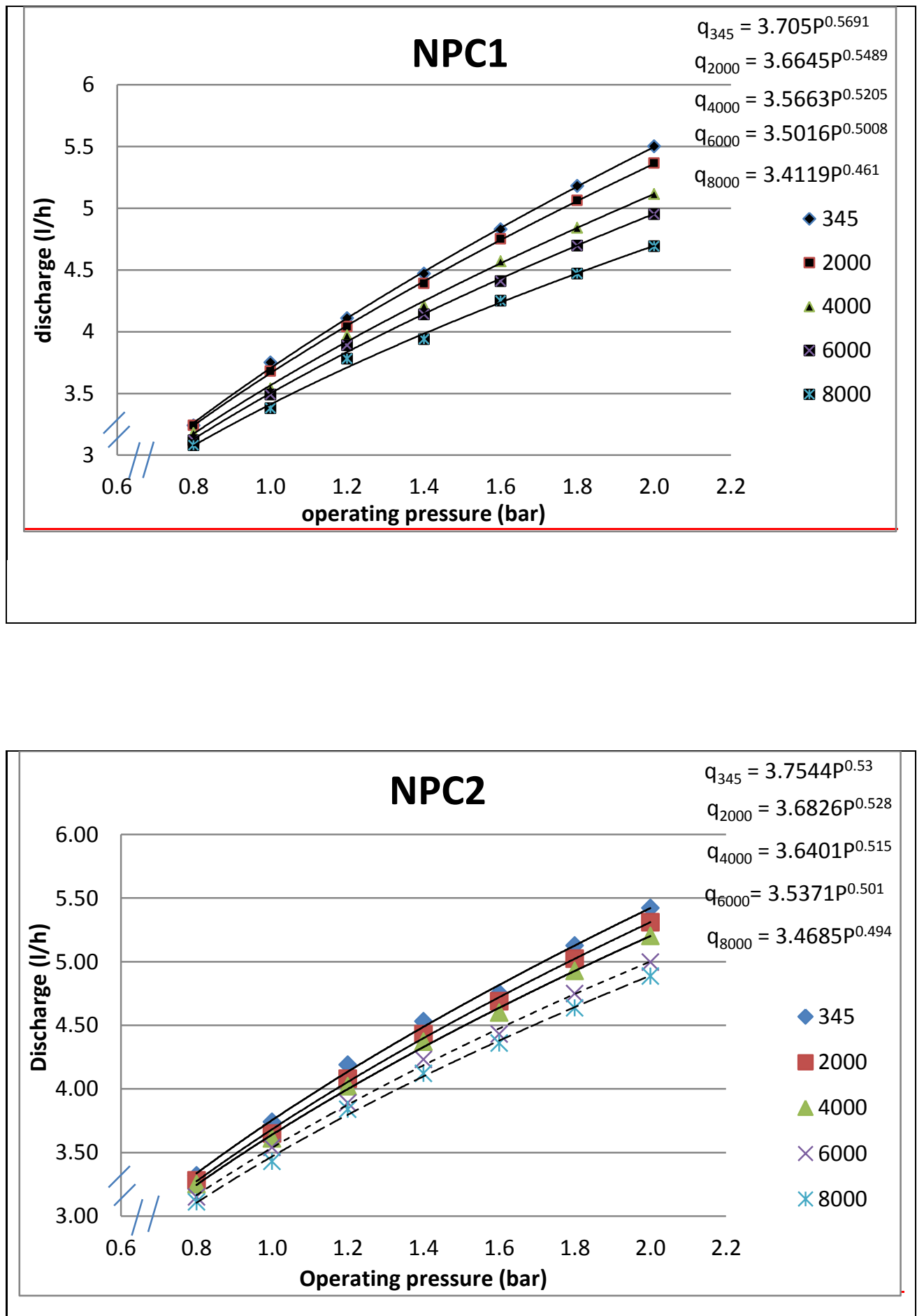

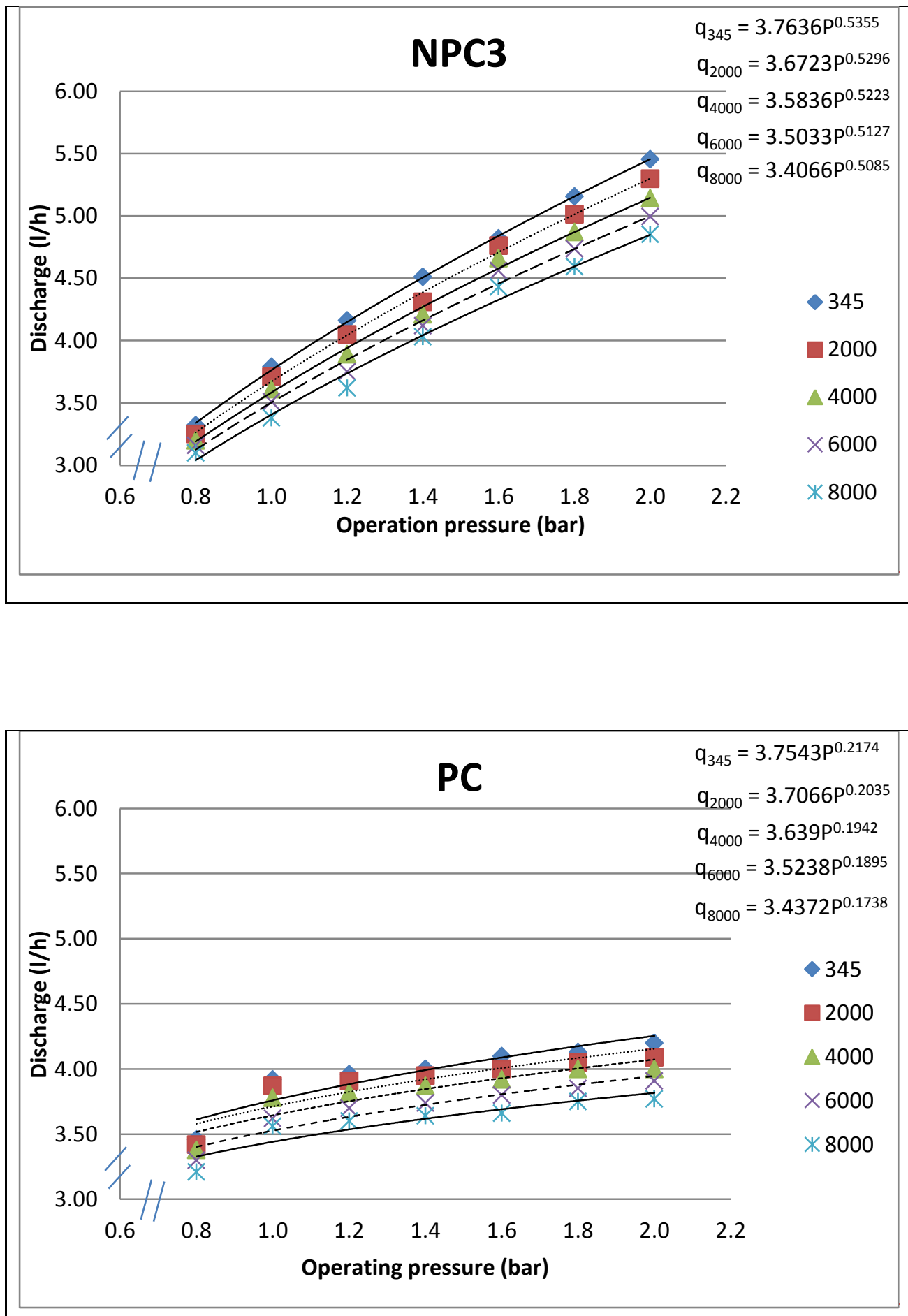


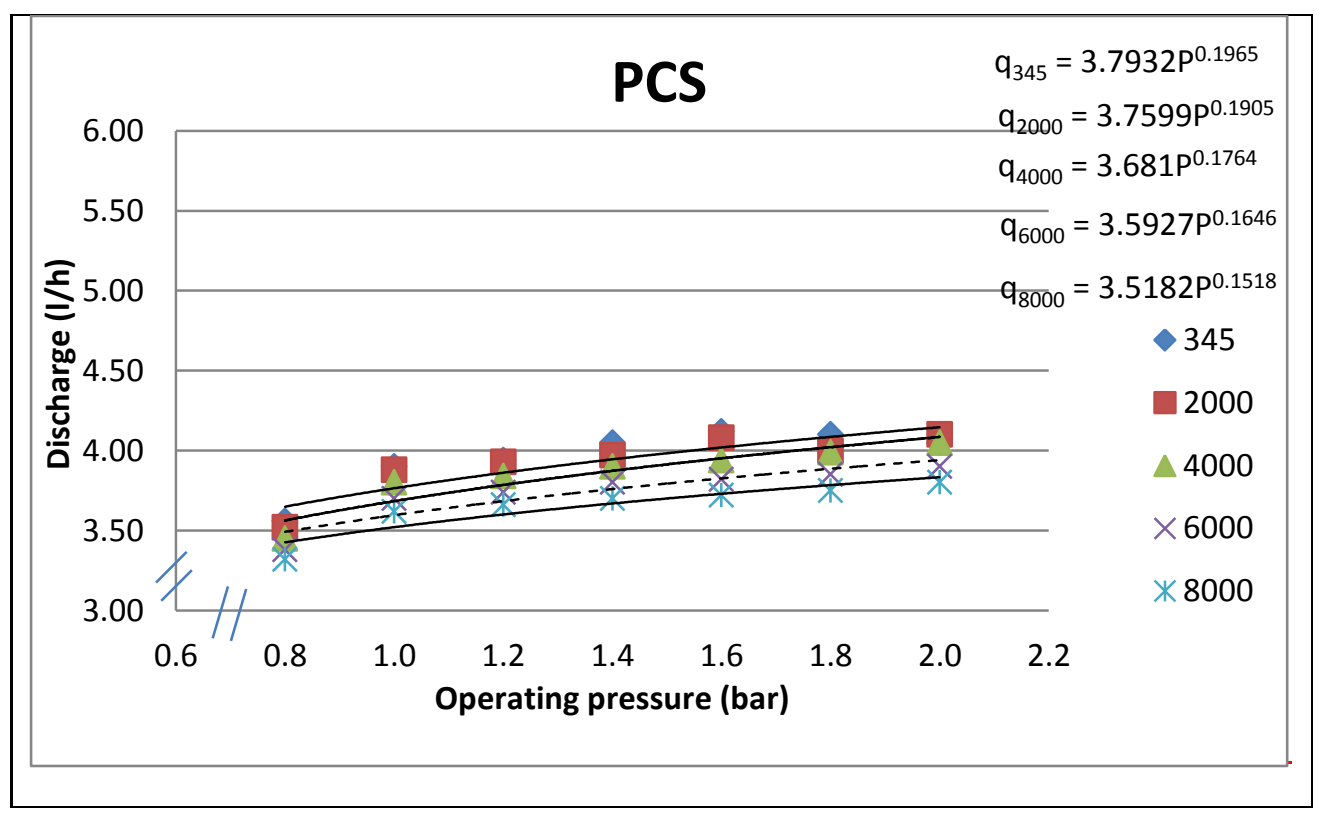

Fig. (4): Effect of water salinity and emitter flow rate.

Meanwhile, the lowest flow rate value $(3.27 \mathrm{l} / \mathrm{h})$ was obtained from PCS at 0.8 bar and the highest value was recorded after operation pressure 1.6 $(4.26 \mathrm{l} / \mathrm{h})$ from emitter NPC1. Additionally, PCS followed by NPC3 recorded the lowest flow rate 3.61 and $3.99 \mathrm{l} / \mathrm{h}$, respectively. And the other tested emitters could be arranged in descending order relative to the flow rate NPC1 $>$ PC $>$ PCS $>$ NPC3 $>$ NPC2. Also, it is worth to mention that the rate of increase flow rate as affected by operation pressure were $4,9,14-3,5,8$ and $3,5,9 \%$ in same sequences, if we compare the emitter flow rate at 1, 2; 1.4 bar comparing with 0.8 bar.

With respect to the water salinity and its effect on the flow rate of the examined emitters, Figure (4) illustrated that PCS and PC were the worthy ones that dramatically decreases their flow rate with increasing water salinity. From the other side, NPC1and NPC3 were the most suitable and moderately affected by water salinity followed by NPC2.

The maximum and minimum numbers of the flow rate of the tested emitters were obtained after canal water and $8000 \mathrm{ppm}$ saline water. In addition, the highest flow rate value relative to water salinity could name as NPC1 (canal), NPC2 (2000 ppm), NPC1 (4000 to 8000 ppm water salinity). From the abovementioned, it is clear to point out that emitter 
named NPC1 followed by NPC2 and lastly NPC3 were not affected strongly by increasing water salinity. Our data was in agreement with those obtained by Almajeed and Alabas (2013), who stated that the main problem is the drop in pressures and discharges distribution in the network resulting from the amount of pressure losses between the head of the lateral as compared with that in the end of the lateral, which affects the discharge distribution of emitters and uniformity.

Table (9): The effect of different emitter types and saline water on clogging percent.

\begin{tabular}{rccccc}
\hline \multirow{2}{*}{$\begin{array}{l}\text { Water } \\
\text { Salinity }\end{array}$} & \multicolumn{5}{c}{ Clogging ratio (\%) } \\
\cline { 2 - 6 } & NPC1 & NPC2 & PC & PCS & NPC3 \\
\hline \hline $\mathbf{3 4 5}$ & 9.58 & 8.36 & 20.45 & 21.36 & 9.33 \\
\hline $\mathbf{2 0 0 0}$ & 10.47 & 10.75 & 24.36 & 22.54 & 10.25 \\
\hline $\mathbf{4 0 0 0}$ & 11.23 & 11.37 & 26.41 & 24.52 & 11.46 \\
\hline \hline $\mathbf{6 0 0 0}$ & 20.54 & 21.64 & 28.36 & 27.8 & 21.36 \\
\hline $\mathbf{8 0 0 0}$ & 22.65 & 22.35 & 29.56 & 26.35 & 23.75 \\
\hline \hline
\end{tabular}

In this research work has been the use of water of varying salinity to test five types of emitters under five different operating pressure and emitter hydraulically tests measured the disposal of all cases, and also calculate the coefficient of variation and uniformity coefficient of each case. It could conclude the regression equations after plotting the primary data on $\log / \log$ paper to get power equation that represents the relation between flow rate and operation pressure for each tested emitter.

According to the data obtained by the relationship between pressure head (bar) and flow rate (1/hr), one can notice that emitter types of NPC1, NPC2, and NPC3 at using water salinity 345, 2000, and 4000 ppm were the best for using and could be recommended to use them the field research work.

\section{Uniformity and coefficient of variation of testing emitter types}

Table (10) and Figure (5) illustrate the effect of emitter type on application efficiency (AE \%), distribution uniformity (DU) and 
coefficient of variation (CV) under (1.0 bar) as a nominal pressure head, one can notice that for $\mathrm{AE}$ and $\mathrm{DU}$, the ranked of emitter type were NPC $3>$ NPC2 $>$ NPC1 $>$ PCS $>$ PC. According to application efficiency, there are significant differences between all values of emitter types. But in respect to distribution uniformity, there are significant between NPC3 and other emitter types, and no significant differences between NPC1 and NPC2 types.

Table (10): The effect of emitter type on Application efficiency, distribution uniformity and coefficient of variation under (1.0 bar) as a nominal pressure head.

\begin{tabular}{|c|c|c|c|}
\hline $\begin{array}{l}\text { Emitter } \\
\text { type }\end{array}$ & $\begin{array}{c}\text { Application } \\
\text { efficiency (AE) \% }\end{array}$ & $\begin{array}{c}\text { Distribution } \\
\text { uniformity (DU) }\end{array}$ & $\begin{array}{c}\text { Coefficient of } \\
\text { variation }(\mathrm{CV}) \%\end{array}$ \\
\hline NPC1 & $93.94 b$ & $0.932 b$ & 0.035 \\
\hline NPC2 & $94.22 \mathrm{c}$ & $0.943 b c$ & 0.10 \\
\hline PC & $82.54 \mathrm{e}$ & $0.836 \mathrm{~d}$ & 0.11 \\
\hline PCS & $82.34 d$ & $0.831 \mathrm{e}$ & 0.09 \\
\hline NPC3 & $94.74 \mathrm{a}$ & $0.938 \mathrm{a}$ & 0.03 \\
\hline $\mathrm{LSD}_{0.05}$ & 0.10 & 0.002 & 0.01 \\
\hline
\end{tabular}

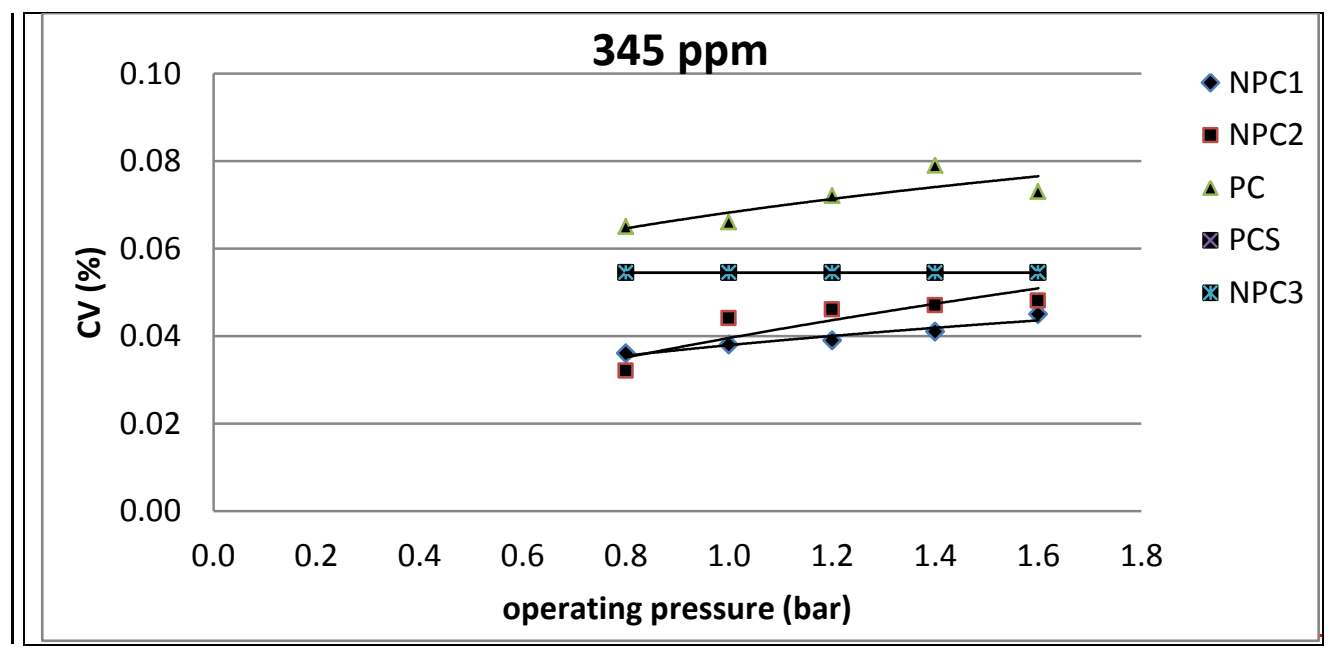




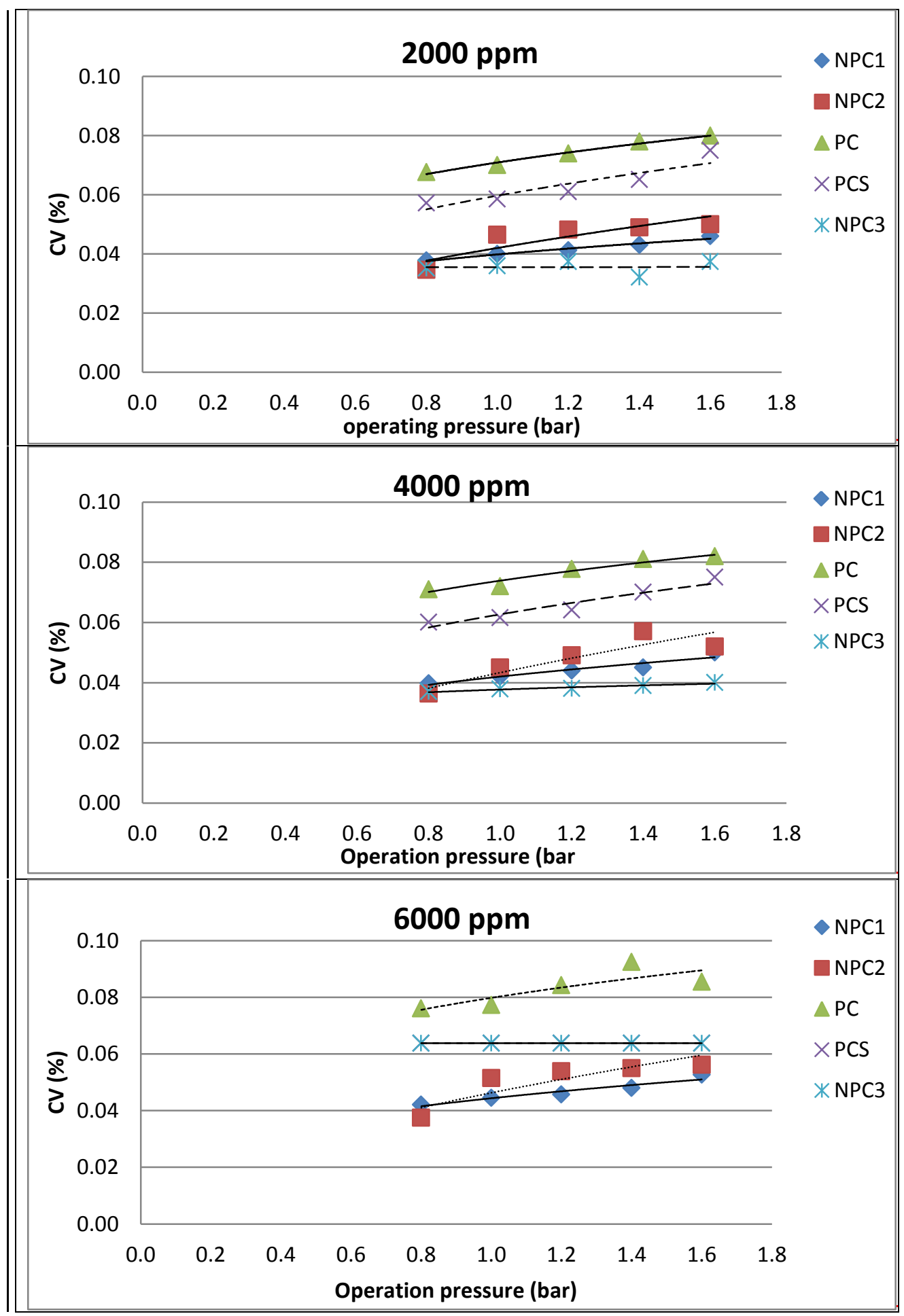




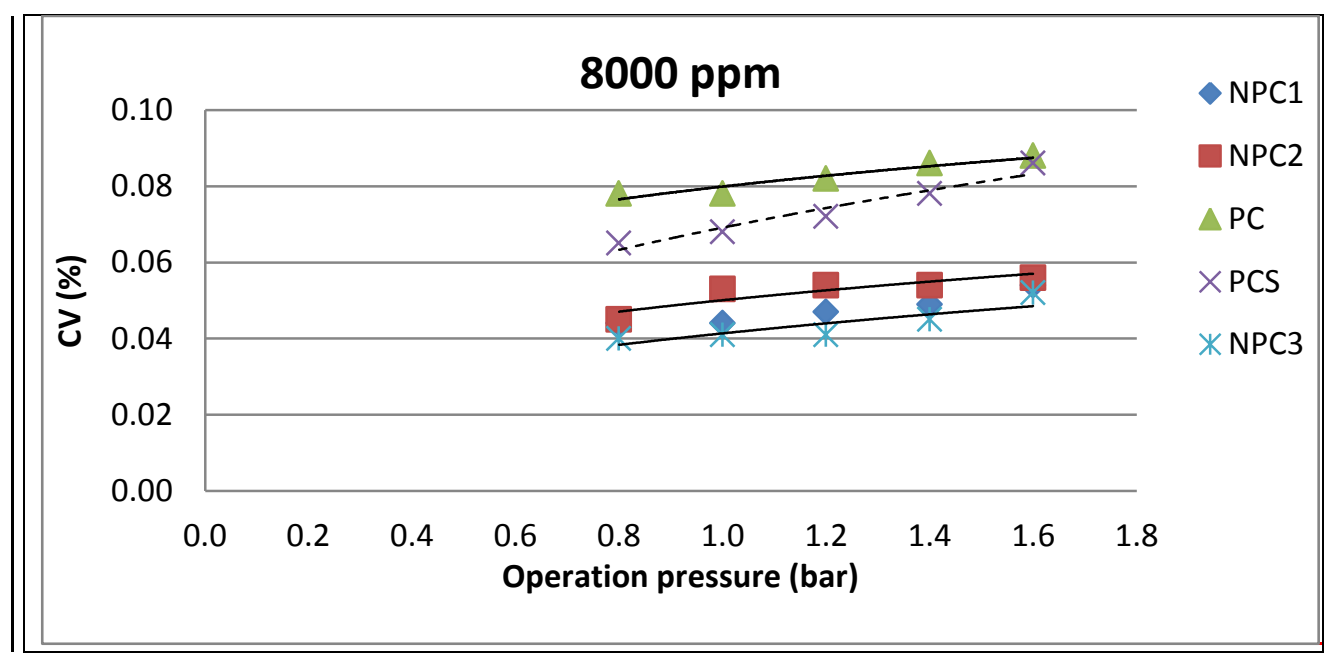

Fig. (5): The effect of emitter type on the coefficient of variation (CV) under different pressure head.

According to AE\% for NPC3 emitter that recorded the highest value (94.74\%), while PCS and counted the lowest AE\% (82.34) and other tested emitters were intermediate among. But it is logical values that obtained belong to the NPC1 (90.94\%) and NPC2 (91.22\%) emitters. Additionally, the lowest performance emitters were PC and PCS emitters due to their lowest AE\% $(89.51 ; 89.85 \%)$. The Same trend was attained after estimated DU; meanwhile, NPC1and NPC2 recorded the same value without significant difference. Whereas, PC and PCS still the lowest DU\%.

Regarding to the coefficient of variation (CV), Table (10) and Figure (5) showed that the rank of emitter types can be in the following order: NPC $3<\mathrm{NPC} 2<\mathrm{NPC} 1<\mathrm{PC}<\mathrm{PCS}$. In addition, we can also notice that there are no significant differences between PC, PCS, NPC1, NPC2 and NPC3 in this concern. Resulted data are in agreement with those obtained by Bralts, et al. (1978); Mansour et al. (2015); Mansour et al. (2016). Obtained results were in line with those obtained by Keller and Bliesner (1990) who reported that emitters are usually classified by the method in which they dissipate pressure or discharge characteristics, for instance, long path, vortex, orifice, flushing, continuous flushing, and multi-outlet emitters. Also, Solomon (1979) mentioned that the efficiency of drip 
irrigation systems depends on the uniformity of emission rates throughout the system. An important factor affecting this uniformity is the unit-tounit variation between emitters. The design of an emitter, the materials from which it is made, and the cares taken in the manufacturing processes affected the amount of such unit-to-unit variation that may be expected. Table (11) and Figure (5) recorded that the effect of both two investigated factors (emitter's type; salinity), data pointed out that DU under NPC3 without change and its value was 0.91 under using water salinity treatments, but NPC1had a highest value more than the other two types with values $0.94(345 ; 2000 \mathrm{ppm})$ and at WS 4000, the value was 0.93 . However, NPC2 emitter got a variation between studied water salinity and values ranged from 0.92 (2000 ppm) and 0.88 (4000 ppm).

This finding is agreed with those obtained by Munns (2002), who reported that salinity stress depresses plant growth and development at different physiological levels. The decrease in plant growth by salinity stress might be related to adverse effects of excess salt onion homeostasis, water balance, mineral nutrition and photosynthetic carbon metabolism.

With respect to DU values, the water amount applied to the crop during the growth season varied from $1824 \mathrm{~m}^{3} / \mathrm{f}$ to $1907 \mathrm{~m}^{3} / \mathrm{f}$ at operation pressure 1 bar. The Same table showed root yield and Water crop productivity as affected by water salinity and emitter's type of turnip crops, it's clear that NPC2 emitter has a superior effect and recorded the highest value which ranged from 18.12 ton/f (4000 ppm) and 23.43ton/f (354 ppm) and $12.8 ; 9.1 \mathrm{~kg} / \mathrm{m}^{3}$ for 345 and $4000 \mathrm{ppm}$, respectively at 1 bar operation pressure. While comparing WCP for examined emitters, NPC2 had a primitive effect and recorded 14.5 and $17.4 \%$ more thanNPC1 and NPC3 respectively.

With respect to salinity effect, it's clear to mention that, increase salinity associated with root yield and WCP. The rate of reduction in yield and WCP relative to salinity were $11.5,2.5 \%$ and $20.1,-3.5 \%$ for irrigation water salinity 2000 and $4000 \mathrm{ppm}$ relative to control one (345 ppm) at 1 and 1.2 bar operation pressure.

Meanwhile, Table (11) and Figure (5) discuss the impact of the investigated two parameters (water salinity and emitter's types) had a promise value or accepted trend. 
Table (11): Distribution uniformity, Yield, and water crop productivity of turnip plant as affected by emitter types and water salinity under 1.0 bar operation pressure.

\begin{tabular}{|c|c|c|c|c|c|c|}
\hline $\begin{array}{c}\text { Dripper } \\
\text { Type }\end{array}$ & $\begin{array}{c}\text { Water salinity } \\
\text { ppm }\end{array}$ & $\underset{\%}{\mathbf{L R}}$ & Du & $\begin{array}{l}\text { Irrigation water } \\
\text { consumed }\left(\mathbf{m}^{3} / \mathbf{f e d}\right)\end{array}$ & $\begin{array}{c}\text { Yield } \\
\text { (ton/fed) }\end{array}$ & $\begin{array}{c}\text { Water crop } \\
\text { productivity }\left(\mathrm{kg} / \mathrm{m}^{3}\right)\end{array}$ \\
\hline \multirow{3}{*}{ NPC3 } & 345 & 10.0 & 0.91 & 1824 & 20.66 b & $11.3 \mathbf{b}$ \\
\hline & 2000 & 15.0 & 0.91 & 1907 & $19.45 \mathrm{c}$ & $10.2 \mathrm{~d}$ \\
\hline & 4000 & 20.0 & 0.91 & 1990 & $16.32 \mathrm{f}$ & $8.2 \mathbf{f}$ \\
\hline \multirow{3}{*}{ NPC2 } & 345 & 10.0 & 0.92 & 1824 & $23.43 \mathrm{a}$ & $12.8 \mathbf{a}$ \\
\hline & 2000 & 15.0 & 0.90 & 1907 & $21.74 \mathrm{~b}$ & $11.4 \mathbf{b}$ \\
\hline & 4000 & 20.0 & 0.88 & 1990 & $18.12 \mathrm{~d}$ & $9.1 \mathbf{e}$ \\
\hline \multirow{3}{*}{ NPC1 } & 345 & 10.0 & 0.94 & 1824 & $19.9 \mathrm{c}$ & $10.9 \mathrm{c}$ \\
\hline & 2000 & 15.0 & 0.94 & 1907 & $17.7 \mathrm{e}$ & $9.3 \mathbf{e}$ \\
\hline & 4000 & 20.0 & 0.93 & 1990 & $15.71 \mathrm{~g}$ & $7.9 \mathbf{f}$ \\
\hline \multirow{3}{*}{$\begin{array}{c}\text { Emitter } \\
\text { type }\end{array}$} & $\mathrm{LSD}_{5 \%}$ & & & 1907 & 18.81 & 9.9 b \\
\hline & & & & 1907 & 21.10 & $11.1 \mathbf{a}$ \\
\hline & & & & 1907 & 17.77 & $9.4 \mathbf{b}$ \\
\hline \multirow{3}{*}{$\begin{array}{c}\text { Water } \\
\text { salinity }\end{array}$} & $\mathrm{LSD}_{5 \%}$ & & & 1824 & 21.33 & $11.7 \mathbf{a}$ \\
\hline & & & & 1907 & 19.63 & $10.3 \mathbf{b}$ \\
\hline & & & & 1990 & 16.72 & $8.4 \mathrm{c}$ \\
\hline
\end{tabular}

DU values were more constant under different emitters and there was no high difference within salinity treatment of each emitter. The highest and lowest values of DU at 1.0 bar were recorded at $(4000 \mathrm{ppm})$ and the lowest one was recorded at $2000 \mathrm{ppm}$ followed by $345 \mathrm{ppm}$. On the other hand, the values were obtained at NPC3 and NPC2 (0.92) and NPC1 (0.91) in same sequences. while at 1.2 bar operation pressure, were $95 \%$ and $93 \%$ were recorded at (NPC3+345 or 2000) and (NPC2 or NPC1 under 345 and 4000) for 1.2 bar, but in the case of ignoring salinity effect, DU NPC3 was better than NPC2 and NPC1 with increase percent $0.7 \%$.The Same trend was obtained in the case of water salinity effect, where 345 and 2000 ppm gained the highest value 94\% and 4000 gained $93 \%$ at 1.02 bar operation pressure. 


\section{REFERENCES}

Aali, K. A., A. Liaghat, H. Dehghanisanij (2009). The effect of acidification and magnetic field on emitter clogging under saline water application. Journal of Agriculture Science, 1(1): 132-142.

Allen, R., Pereira L.S., RaesD.and Smith M. (1998). Crop evapotranspiration -Guidelines for computing crop water requirements. FAO Irrigation and Drainage Paper

Almajeed, A. and A. Alabas (2013). Evaluation the hydraulic performance of drip irrigation system with multi-cases. Global Journal of Researches in Engineering, 13(2): 13-18.

Amor, Z. H., N. Feki and S. Bouri (2014). Irrigation water management in a Southern continental oasis of Tunisia. Journal of Environmental Science, Toxicology and Food Technology. 8(3): 48-58.

ASABE Standards. 50th Ed. 2008R. EP 405. Design and installation of microirrigation systems. St. Joseph, Mich,: ASABE.

Bozkurt, S. and Ozekici B.(2006).Effects of Fertigation Managements on Clogging of In-Line Emitters. Journal of Applied Science 6 (15): 3026-3034.

Bralts V.F., Edwards D.M. and Wu I. (1987). Drip irrigation design and evaluation based onstatistical uniformity co-efficeint, Adv.Irriga., 4(2), $67-117$

CIT (Center for Irrigation Technology)(2002). Irrigation Performance Report. CATI Publication No.020102.

Cuenca, R.H. (1989). Irrigation Systems Design: An Engineering Approach, Englewood Cliffs, N.J. Prentice-Hall: 317-350.

Dospekhov, B.A. (1984).Field experimentation. Statistical procedures. Mir Publishers, Moscow.

El-Berry A.M.Sharaf G.A., Azza H. andEbtsam S. (2003). Irrigation scheduling of sunflower with drip irrigation system in newly reclaimed land. Misr J. Agric. Eng. 20(4);993-1010. Earl KD, Jury WA (1977). Water

Hebbar, S. S., B. K. Ramachandrappa, H. V. Nanjappa and M. Prabhakar (2004). Studies on NPK drip fertigation in field grown tomato (Lycopersicon esulentum Mill.). Eur. J. Agron., 21: 117127. 
Hezarjaribi A., A. A. Dehghani, M. M. Helghi and A. Kiani (2008). Hydraulic Performances of Various Trickle Irrigation Emitters. Journal of Agronomy, 7: 265-271.

Hill R. and Koenig R.T.(1999). Water Salinity andCrop Yield .May 1999 Utah Water Quality AG-425.3.

Keller, J. and D. Karmeli. 1974. Trickle irrigation design parameters. Trans. ASABE, 17: 0678-0784.

Keller, J. and R.D. Bliesner(1990). Sprinkler and Trickle Irrigation. New York: Van Nostrand Reinhold SAVVA and Karen Frenken- volume1, module1-6.

Koegelenberg, F. H., G. Conradie, and G. Voedingsbesproeiing (1999). ARC-Institute for Agricultural Engineering, Silverton, Pretoria, RSA.

Kulkarni, S. A. (2005). Looking Beyond Eight Sprinklers. Paper presented at the National Conference on Micro-irrigation.University of Agriculture and Technology, Pantnagar, India.

Madramotto, C.A.(1988). Effect of pressure changes characteristics on the discharge characteristics of pressure compensatingemitters. J.Agri. Engg. Res. 40: 159-164.Wu, I.P. and Giltin , H.M. (1977) Drip irrigation efficiency and schedules . Trans of theASAE,26(I):92-97.

Mansour, H. A., M. Abd El Hady and C. Gyuricza (2013). Effect of localized irrigation systems and humic compost fertilizer on water and fertilizer use efficiency of maize in sandy soil. International Journal of Agricultural Science Research, 2(10): 292-297.

Mansour H. A., Abdel-HadyM., Ebtisam I. Eldardiry and BraltsV. F.(2015). Performance Of Automatic Control Different Localized Irrigation Systems And Lateral Lengths For: 1- Emitters Clogging And Maize (Zea Mays L.) Growth And Yield. Int. J. of GEOMATE, Dec., 2015, Vol. 9, No. 2 (Sl. No. 18), pp. 1545-1552, Geotech., Const. Mat. andEnv., ISSN:2186-2982(P), 2186-2990(O), Japan.

Mansour, H. A. , Abd El-HadyM., Bralts V. F.and EngelB. A.(2016). Performance Automation Controller of Drip Irrigation System and Saline Water for Wheat Yield and Water Productivity in Egypt. Journal of Irrigation and Drainage Engineering, American Society 
of Civil engineering (ASCE), J. Irrig. Drain Eng. 05016005 http://dx.doi.org/10.1061/(ASCE)IR.1943-4774.0001042.Online Publication Date: 24 May 2016

Munns, R.(2002). Comparative physiology of salt and water stress. Plant Cell Environ., 25: 239-250.

Ozekici, B. (1998). Clogging factors in drip irrigation systems. Final Report, University of Cukurova, Faculty of Agriculture, Department Research Project and C.U. Rectorate Research Fond BAP-TYS-9506, Adana.

Phocaides, A. (2000). Technical handbook on pressurized irrigation. Techniques Food and Agriculture Organization of the United Nations, Rome.

Reinders, F. B., H. S. Smal, A. S. van Niekerk, S. Bunton, and B. Mdaka (2005). Sub-surface drip irrigation: Factors affecting the efficiency and maintenance. WRC Report NoK5/1189/4.

Ribeiro, T. A., J. E. Paterniani, R. P. Airoldi and M. J. Silva (2004). The water quality effect in the clogging of emitters and the performance of filters utilized in the trickle irrigation. Irrigat., 9(2): 136-149.

Sanij H.D., Torabi M. and MirlatifiM.,Singh H.P., Kaushish S.P., KumarAshwani, Murthy T.S. and Samuel Jose C. (2001). Effect of water quality and irrigation management on emitter clogging in Southeast of Iran, Microirrigation : 1st Ed., 537-545

Shinde, D. G., K. G. Patel, B. M. Solia, R. G. Patil, B. M. Lambade and A. R. Kaswala (2012). Clogging behaviour of drippers of different discharge rates as influienced by different fertigation and irrigation water salinity levels. Journal of Environmental Research and Development, 7(2): 917-922.

Solomon, K. (1979). Manufacturing variation of emitters in trickle irrigation systems. Trans. ASAE, 22: 1034-1038.

Uys, P. M. (2000). Towards the virtual class: Key management issues in higher education. Unpublished Ph.D. thesis, Victoria University of Wellington, New Zealand.

Van Niekerk, A. S., F. H. Koegelenberg, F. B. Reinders, G. W. Ascough (2006). Guidelines for the selection and use of various 
Micro-Irrigation filters with regards to filtering and backwashing efficiency. Water Research Commission. WRC Report K5/1356/4.

Wan S, Kang Y, Wang D, Liu SH and Feng L (2007). Effect of drip irrigation with saline water on tomato (Lycopersiconesculentum) yield and water use in semi-humid area. Agric Water Manage 90: 63-74.

\section{الملخص العربي \\ دراسات هيدروليكية لنظام الرى بالتتقيط تحت ظروف استخدام

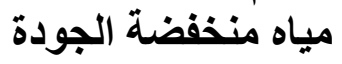

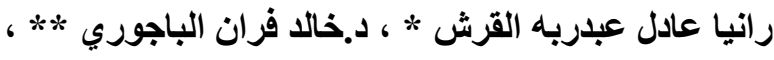

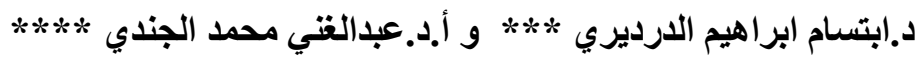

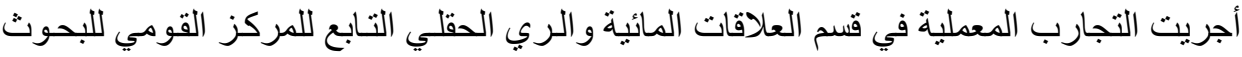

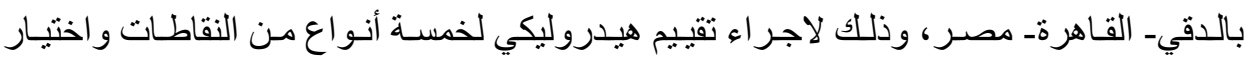

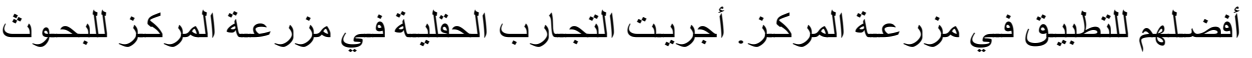

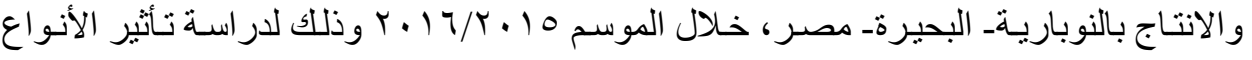

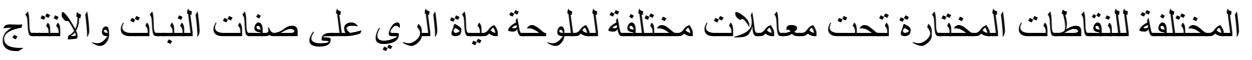

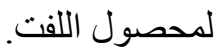

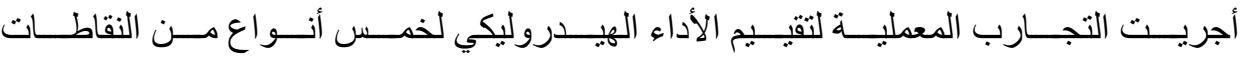
، Built in (GR) ،On-line emitter NEIN-ETF)

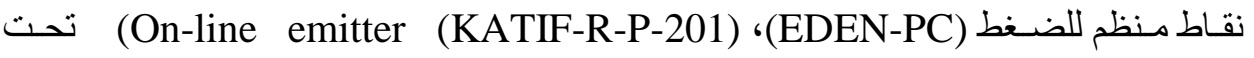

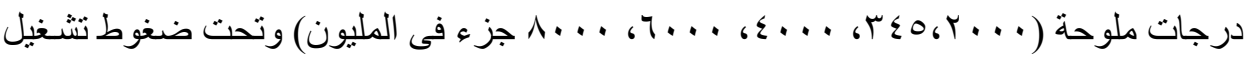

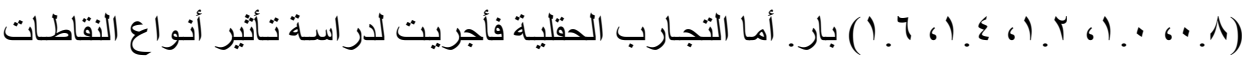

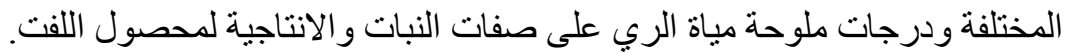

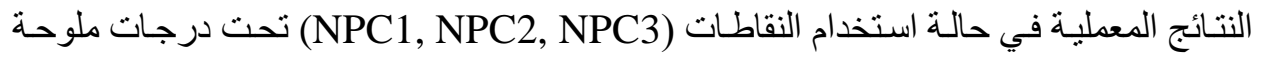

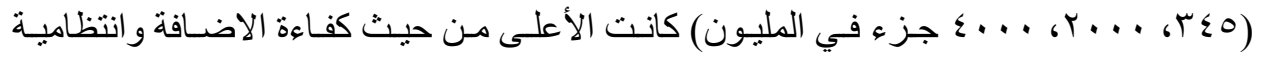

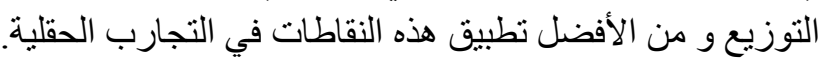

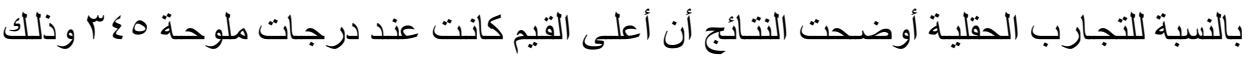

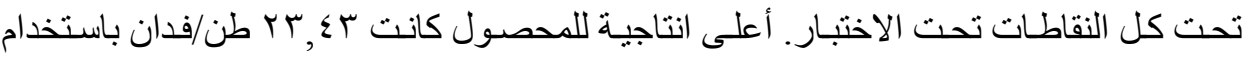

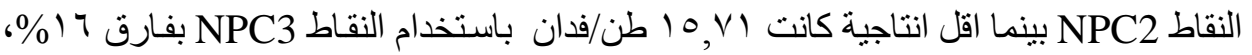

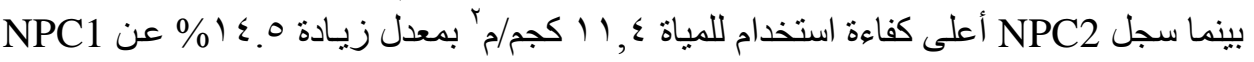

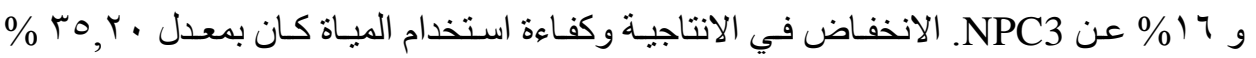

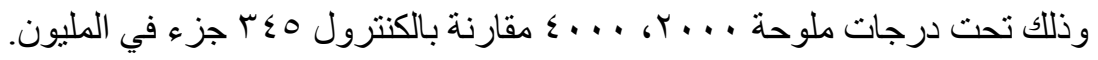

*مساعد باحث،المركز القومي للبحوث.

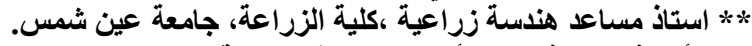

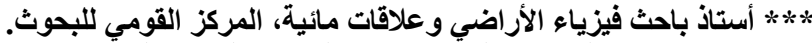

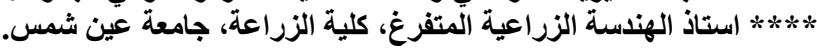

